\title{
From written records to seismic parameters: the case of the 6 April 1667 Dalmatia earthquake
}

\author{
Paola Albini" (1) and Andrea Rovida
}

\begin{abstract}
On Wednesday 6 April 1667, an earthquake occurred, and severely affected a large area of the eastern coast of the Adriatic Sea, also known as southern Dalmatia, in today Croatia, and part of Montenegro. This paper summarizes the seismological data existing today on this large earthquake, with special attention to how such data were gathered by means of investigating hitherto not considered historical sources of earthquake records. The obtained set of 37 macroseismic intensities in European Macroseismic Scale-EMS98 was processed, to obtain an epicentre located not far from the most damaged places, amongst them Ragusa (today Dubrovnik), and an Mw value of $6.4 \pm 0.3$.
\end{abstract}

Keywords: Written accounts on earthquakes, Earthquake records, Seismic parameters, 6 April 1667 Dalmatia earthquake

\section{Background}

The scientific challenge faced by historical seismology is to reconstruct an earthquake by making use of written observations of its effects, taking into account that such records were not originally intended to be used for seismological purposes. The substantial questions posed are the following:

- When did the earthquake occur?

- At which places was it felt?

- Which was the intensity of the shaking at each place?

To look for the surviving written records dealing with that specific earthquake's time and area is not much different from a trip back in time. The affected area may have been transformed by succeeding natural or anthropogenic events, and the records contemporary to the earthquake may have disappeared. The quest for the testimonies left by the earthquake observers, i.e. those testimonies which withstood the passing of centuries, is just the first step of a systematic and painstaking

*Correspondence: paola.albini@ingv.it Istituto Nazionale di Geofisica e Vulcanologia, Sezione di Milano, Via E. Bassini 15, 20133 Milan, Italy reconstruction of what actually each individual place experienced the moment when the earth quaked, and its aftermath.

An earthquake struck on Wednesday 6 April 1667, and severely affected a large area pertaining to the southern Adriatic domain, characterised by compressional deformation, related to the Dinarides NW-SE-oriented active thrust belt (Anderson and Jackson 1987; Ivančić et al. 2006).

This case study is presented according to what can be considered a "classical" scheme in the investigation of historical earthquakes, and was accordingly adopted for the in-depth reconstruction recently published by Albini (2015). The readers are referred to the extensive account just mentioned for a description of the geographical and historical scenario in which the earthquake happened, a review of previously published studies, and details on the original sources and their authors. This study is indeed intended to complement the monograph by Albini (2015) in accounting for the adopted, "without borders" research strategy, and to push forward the seismological interpretation, further than the macroseismic intensities, to propose a new location and magnitude of the 6 April 1667 earthquake. Eventually, all scientific steps performed, the 
course of the research "from written accounts to earthquake parameters" is completed.

\section{Searching for observers and their accounts}

On the eve of the earthquake, i.e. in mid-17th century, Dalmatia (today Croatia) together with the coastal part to its immediate south, then known as "Albania Veneta" (today Montenegro), was controlled by three different states (Fig. 1):

- The Republic of Ragusa, named after its capital, corresponding with modern day Dubrovnik, at the very heart of the Dalmatian region;

- The "Serenissima" Republic of Venice, with a highranking governor ("Provveditore Generale") taking care of the Venetian possessions in this strategic region on the route to the East;

- The Ottoman Empire, or "Sublime Porte", which ruled all over the Balkans and most of Hungary at the time, in a sense enveloping, from the mainland, the territories of the Republics of Venice and Ragusa.

Such an international stage asked for a research concentrated on retrieving as many contemporary written accounts as possible, in their original version and pristine language (Albini 2015). This was a step particularly relevant in preventing substantial mistakes in the succeeding phases of interpretation, as spotted in some previous studies of this earthquake. Table 1 shows the visited repositories, and details the languages in which the consulted documents were originally written.

The amount of documentary material retrieved was overwhelming, as the earthquake and its effects were the subject of a variety of documents, such as:

- official documents and letters of the "Rettore" and "Consiglieri" of the Republic of Ragusa,

- dispatches, official surveys of damage, and pleas of citizens and officers of the Republic of Venice,

- private letters, which are the greatest part of the collected material, mostly unpublished and not considered so far,

- printed reports, often extracted from private letters, to complete this set of sources.

All the collected items underwent a thorough analysis, to ascertain:

- the date when the item was produced,

- who authored it,

- the place where the item was actually written,

- to whom the item was addressed.

Full references and details, including each item's archiving and/or cataloguing position of the 114 documents dated within 2 months from the earthquake, are included

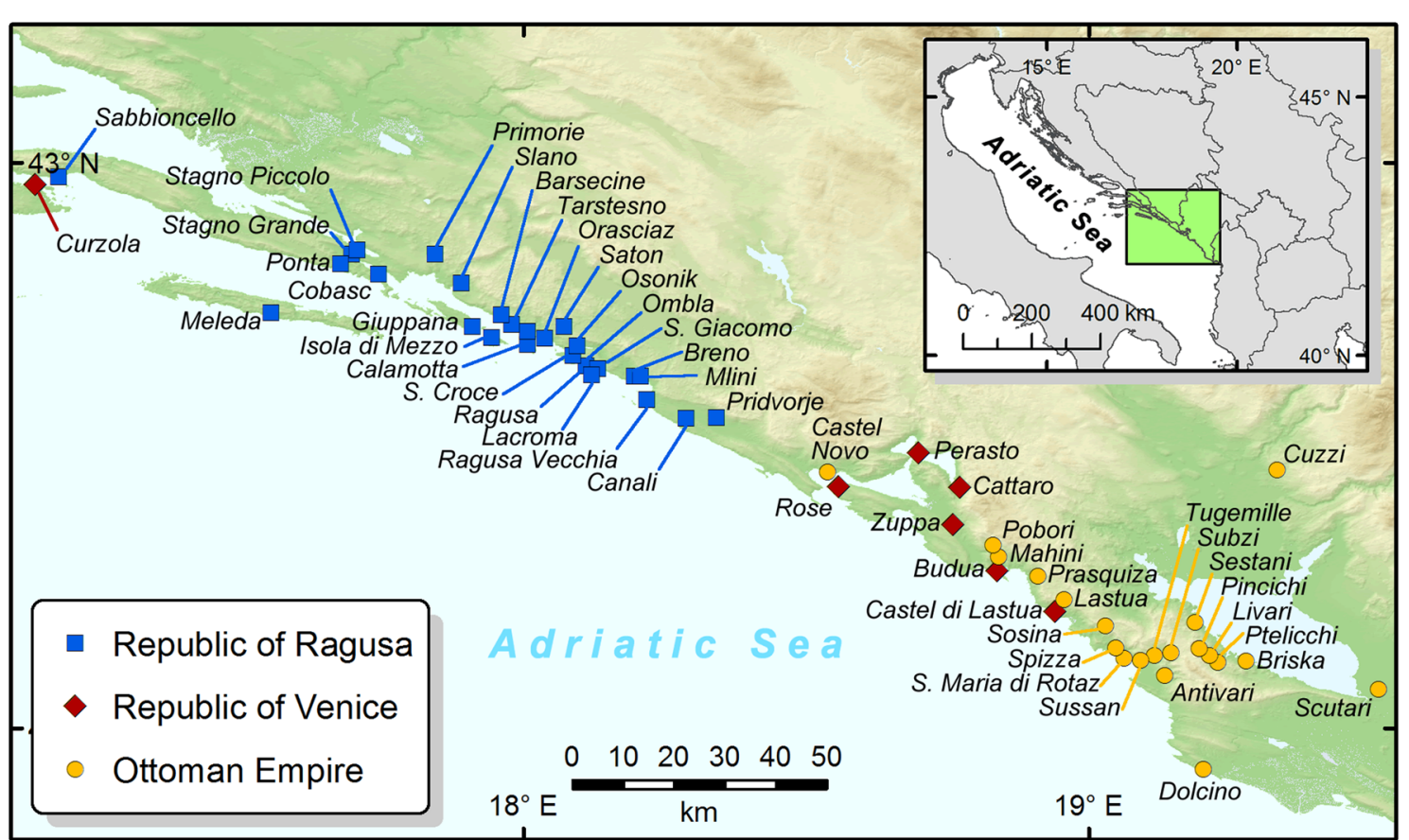

Fig. 1 Dalmatia and neighbouring areas around 1667, and places mentioned. The area was then ruled by three different countries, the Republic of Ragusa, the Republic of Venice, and the Ottoman Empire 
Table 1 Locations and names of visited repositories, and languages in which consulted documents were originally written

\begin{tabular}{lll}
\hline Place & Repository & Documents' languages \\
\hline Dubrovnik (Croatia) & Državni arhiv u Dubrovniku (State Archive of Dubrovnik) & Latin, Italian, Croatian, and Dalmatian dialect \\
& Library of the San Domenico Monastery & Latin \\
Venice (Italy) & Archivio di Stato di Venezia (State Archive of Venice) & Latin and Italian \\
& Civico Museo Correr & Italian \\
London (UK) & National Archives, Kew Gardens & English \\
& British Library & English, French, Dutch, and German \\
Paris (France) & Bibliothèque Mazarine & French \\
Vienna (Austria) & Österreichische Nationalbibliothek (National Library of Austria) & Italian \\
Zadar (Croatia) & Državni arhiv Zadar (State Archive of Zadar) & Italian \\
\hline
\end{tabular}

in the "Extra Materials" to Albini (2015). Through a careful selection, a homogeneous set of accounts relevant to an unbiased reconstruction of the earthquake effects was obtained. The 86 identified documents are authored by 32 different earthquake observers, 18 of them living inside the territory of the Republic of Ragusa. They had to be complemented by a few later documents, written by travellers (Molin 1668), or eyewitnesses, who later left the area (Loredan 1669), or came back on a new assignment (Zmaievich 1671).

The variety emerging from the analysis of the accounts reverberates the many and various situations the earthquake observers found themselves in. The following overview gives prominence to some of the observers by adopting their perspective, to retrace their locations and actions in the days immediately after the earthquake.

Of the many eyewitnesses who were inside the territory of the Republic of Ragusa, five portrayed their adventure so extensively, to make it possible to detail in Fig. 2:

- the sea travel's routes they took to get to safer havens, their stops, and travel times (from 8 April to 2 May 1667);

- their intermediate or final destinations.

In the days immediately after the earthquake, the stretch of sea running parallel to the eastern Adriatic Sea became a very-well travelled route by Venetian envoys and officers, heading either away from or towards the affected areas (Fig. 3). The motive of this bustle was that about $80 \mathrm{~km}$ to the southeast of Ragusa was located another important town of that time, Cattaro, then ruled by the Republic of Venice. The local Venetian authorities ordered "Monsignor" Triffon Drago to leave Cattaro, $2 \mathrm{~h}$ after the earthquake, and he arrived the day after in the port of Santa Croce, close to Ragusa. He was followed closely behind by another inhabitant of Cattaro, Vicenzo Giumeta, and both were travelling separately to report to Caterino Cornaro, the Venetian "Provveditore Generale in Dalmatia et Albania" in Zara (Fig. 3). In the same days (7-9 April 1667), Francesco Miutini left Curzola, a Venetian-ruled island, to check with his own eyes the situation of the Republic and its capital Ragusa, though unsuccessfully. On 11 and 12 April, the two envoys from Cattaro reached Zara, and reported to Caterino Cornaro. Francesco Miutini added to the group of Venetian officers who took care of facing the earthquake's effects, and accompanied Caterino Cornaro in his trip from Zara to Cattaro, where they arrived on 20 April.

Being Caterino Cornaro the only Venetian high-ranking officer who had the authority to start an action to rescue and aid the inhabitants of the damaged settlements, he took with him also the engineers Benaglio and Moretti, who immediately performed their surveys. Their documents are supplemented by the report of the Provveditore in charge of Cattaro, Giacomo Loredan.

Also worth mentioning amongst the earthquake observers is Andrea Zmaievich, who was in Perasto (Fig. 1), back in 1667 a Venetian-ruled settlement also. Appointed archbishop of the diocesis of Antivari in 1671, he made a pastoral visit in which he complemented his direct experience of the earthquake with the information collected in the diocesis, a territory then under the rule of the Ottoman Empire. In this way, he contributed with-so far unknown-data on 15 settlements, located in Montenegro and Albania, somehow affected by the 1667 earthquake.

After carefully considering how the news spread in the affected area, further considerations were made to learn how many days the news of the earthquake needed to break out, and especially what routes the news took.

The earliest flow is concentrated in the first 10 days after the earthquake and was restricted to both coasts of the Adriatic Sea, originating from Ragusa and Cattaro (see Figs. 2, 3). Another massive wave of information (Fig. 4) circulated from the town of Ragusa to important 


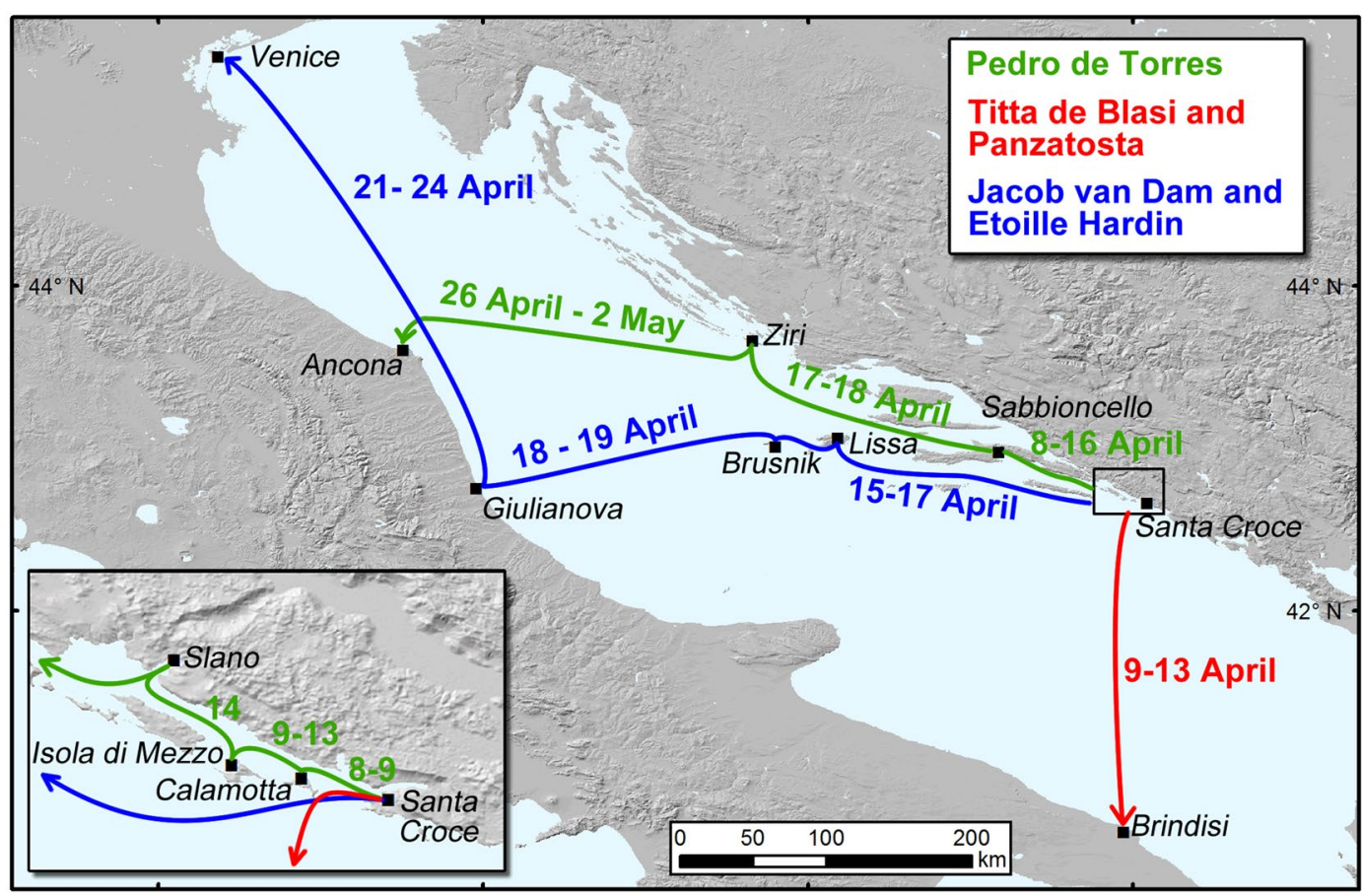

Fig. 2 Eyewitnesses leaving Ragusa after the 6 April 1667 earthquake. Pedro de Torres, archbishop of Ragusa, who found a temporary shelter in Ancona with 62 survived nuns; the Italian merchants Titta de Blasi and Panzatosta, who went straight back home, in Brindisi (Italy); Jacob van Dam, a Dutchman of a diplomatic team of 40 , on route to Izmir and Constantinople, who travelled to Venice together with Etoille Hardin, a French tradesman. From Albini (2015), modified

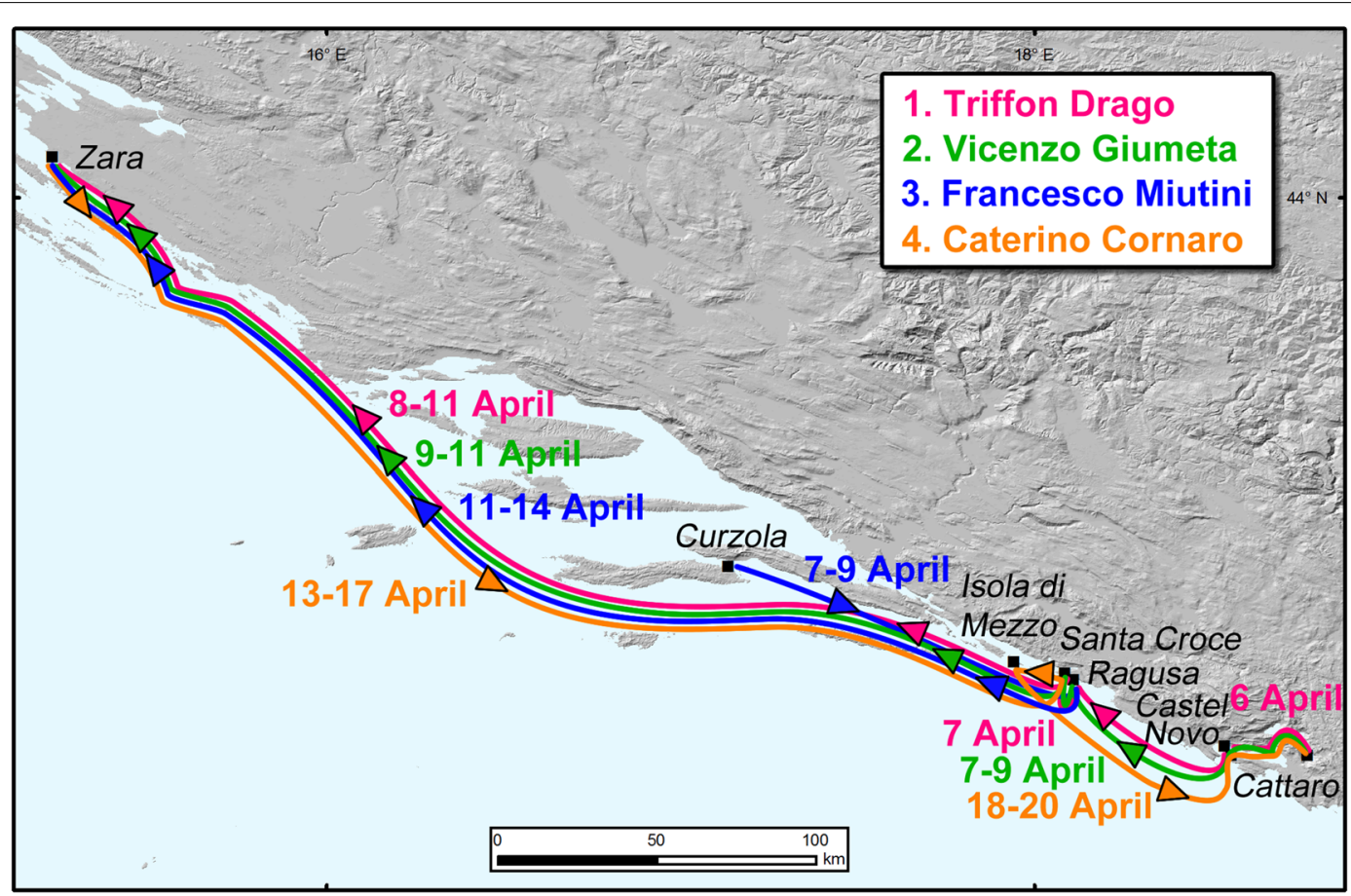

Fig. 3 Venetian officers and citizens travelling the Adriatic Sea in the 2 weeks after the earthquake. (1) and (2) from Cattaro to Zara; (3) from Curzola to Santa Croce and then Zara; (3) and (4) from Zara to Cattaro. From Albini (2015), modified 


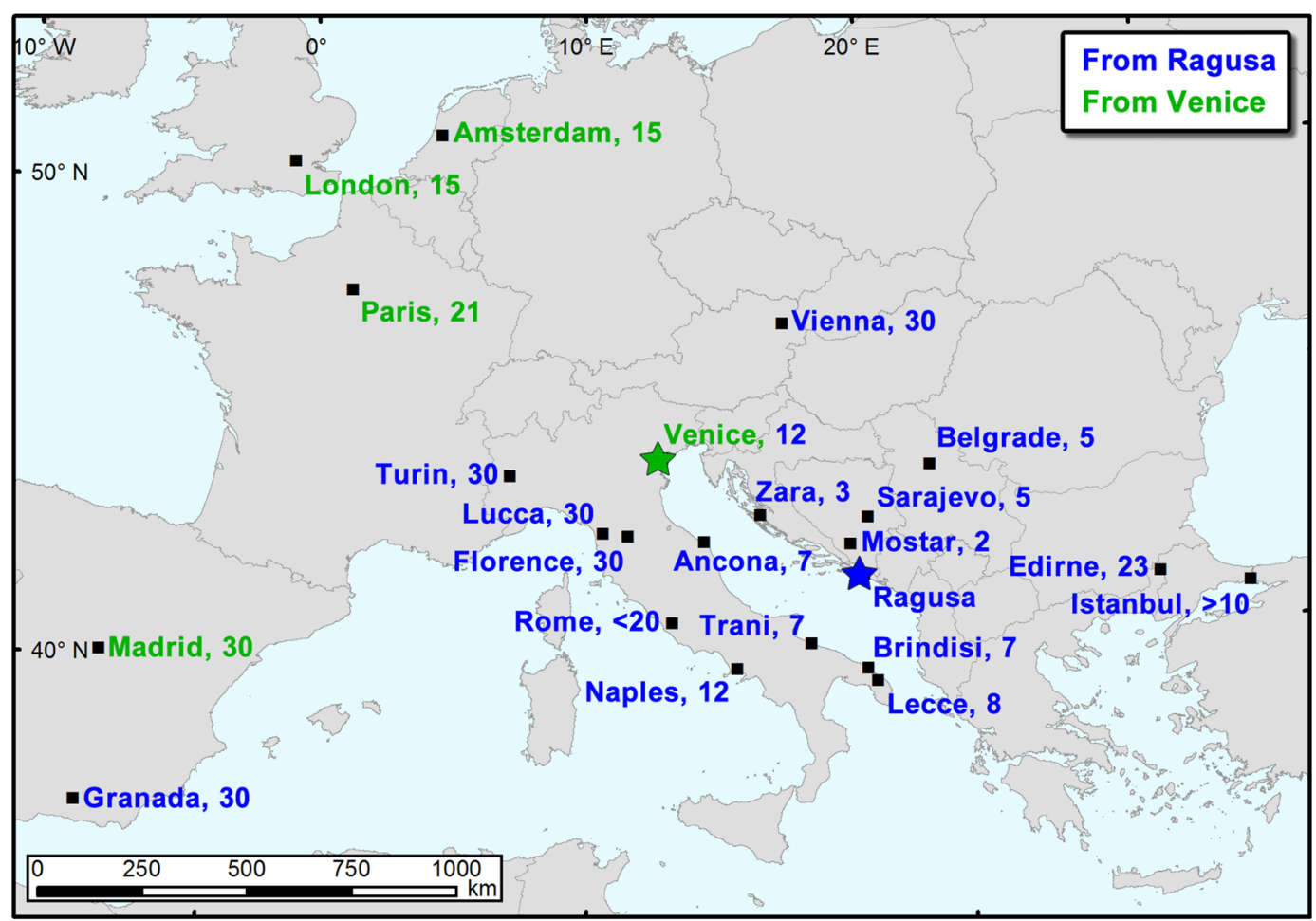

Fig. 4 Breaking news, from Ragusa and from Venice. From Albini (2015), modified

settlements immediately out of the territory of the Republic, and in less than 10 days spread further inland, in the Balkans. Eventually, around 21 April, i.e. 2 weeks from the earthquake, Venice became the centre of irradiation of the news throughout the rest of Europe, through well-established diplomatic channels.

\section{Earthquake records, macroseismic intensities, and seismic parameters}

After retrieving and organizing them, the written accounts had to be further interpreted to obtain proper earthquake records. A "record" is here defined as only that part of the description supplied by each observer that turned out to be meaningful for seismological purposes.

As clearly shown in Fig. 5, records are unevenly distributed amongst the 37 settlements that, according to the coeval documentation, were affected by the 6 April 1667 earthquake. For 8 places out of 37, records are abundant (i.e. $\geq 10$ ), and-not surprisingly-this is true especially for the towns of Ragusa and Cattaro. For 9 more places, 2-8 records are available, whilst for the remaining 20 a unique record contained observations relevant to intensity assignment.

Another way to look at this is to compare observers and records with the number of places at which effects were described, according to the country they belonged in 1667. Although there is not an univocal correspondence between the country of origin of the observer and the place(s) he accounted for (e.g. Venetian observers did report about neighbouring towns pertaining to the Ottoman Empire), Table 2 helps understanding the real improvement in the knowledge of the effects' distribution of this earthquake, in terms of the increased number of records and places they deal with.

Moving the attention from the observers and their records to the settlements, it is possible to finally assess how strong the shaking at each place was. Criteria and diagnostics of EMS98, as clearly expressed in the guidelines by Grünthal (1998), were taken into account, with the addition of quantitative details on size and number of inhabitants of each settlement (Musson and Cecić 2002), as detailed in Albini (2015).

The 37 intensity values in EMS98 are presented in Tables 3, 4 and 5, according to the geopolitical and administrative pertinence of each place (see Fig. 1), the indication of place names in the year 1667, their corresponding modern ones, and the country they today belong to. The intensity distribution is mapped in Fig. 6, also.

The territory of the Republic of Ragusa was undoubtedly the most damaged of the three countries affected by 


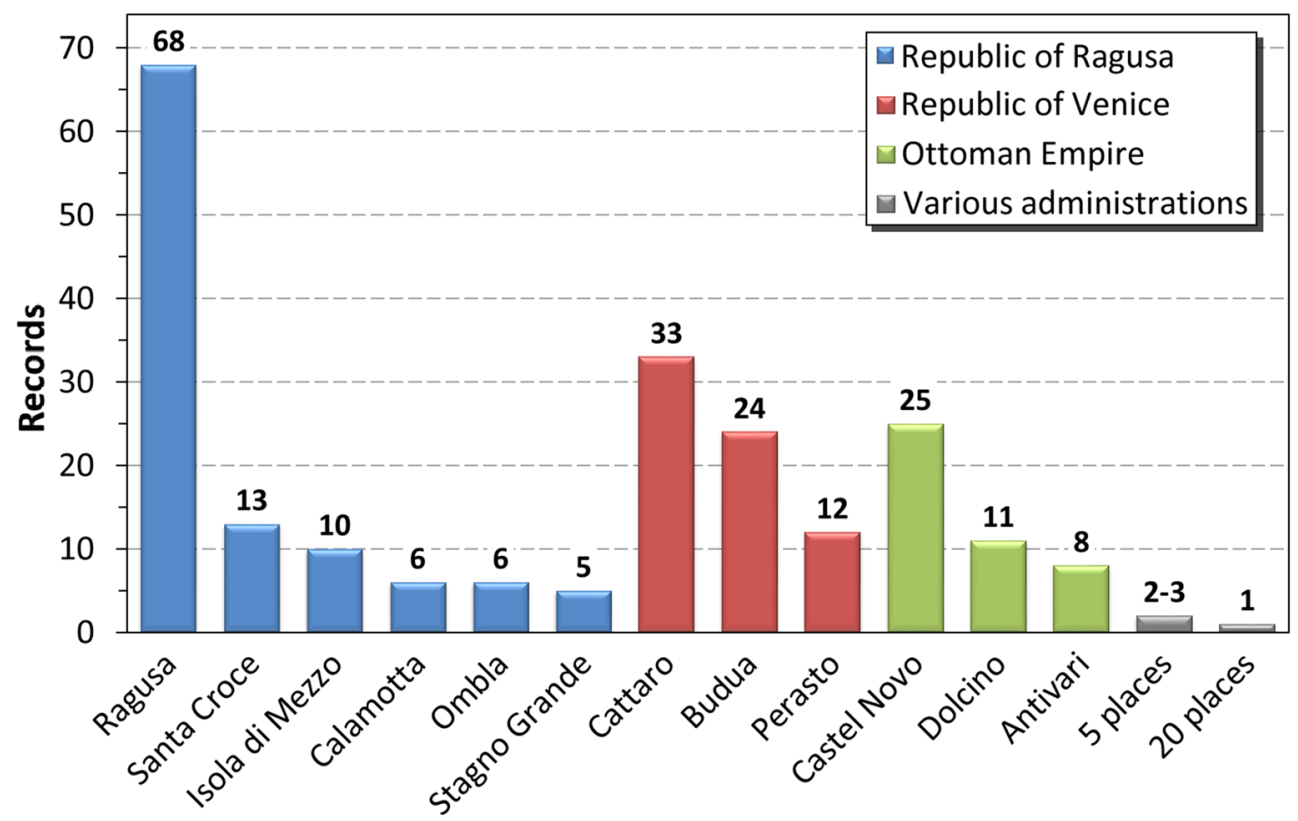

Fig. 5 Amount and pertinence of 253 earthquake records for 37 settlements in the area of the 6 April 1667 earthquake. From Albini (2015), modified

Table 2 Observers, records and places, according to their country of origin in 1667

\begin{tabular}{llcc}
\hline Country in $\mathbf{1 6 6 7}$ & No of observers & No of records & No of places \\
\hline Republic of Ragusa & 18 & 128 & 22 \\
Republic of Venice & 10 & 75 & 7 \\
Ottoman Empire & 4 & 50 & 8 \\
Total & 32 & 253 & 37 \\
\hline
\end{tabular}

the 6 April 1667 earthquake. A maximum intensity value of 9 EMS98 was assigned at three close places, Ragusa, Ombla and Santa Croce (Table 3). No reliable earthquake records were found related to Lacroma (Lokrum, Island of), Sabbioncello (Orebić), and Cobasc (Kobaš), and consequently no intensity values were assigned.

The Venetian enclave in today Montenegro suffered heavy damage in all his main settlements (Table 4). The largest toll was exacted from Cattaro, with an intensity of 8 EMS98, and 250-300 people dead in a town of approximately 1300 inhabitants.

Castel Novo, located in the Bocche di Cattaro, was the most damaged settlement in the territory then ruled by the Ottoman Empire (Table 5). No intensity was assigned at Rose (Rose) in the Bocche di Cattaro, Cuzzi (Kuci), in today Montenegro (see Fig. 1), and Mostar (Mostar), to the north-west of the town of Ragusa, currently Bosnia and Herzegovina, all under Ottoman rule at that time.

The scarcity of information on this area may be further filled by searching into Ottoman sources, which were not considered by this study. In addition, for 12 places visited by Zmaievich (1671) no record of any kind of earthquake effect was found. These places are Sussan (Šušanj), Santa Maria di Rotaz (Santa Maria di Ratac), Spizza (Sutomore), Sosina (Sozina), Marcovicchi (Mercòvici), Briska (Donja Briska), Livari (Livari), Pincichi (Pinčići), Sestani (Šestan), Monasterio di Prasquiza (monastery near Čelobrdo), Pobori (Pobori), and Mahini (Maini).

The only reference to earthquake-related effects was found in report by the Franciscan friar Vitale Andriasci (1667): "The sea receded, then raised two fathoms (in the town harbour of Ragusa), and maintained this change in its natural level for the space of three days". His description was interpreted beyond question and by all 20th century seismological studies as the testimony of a seawave triggered by this earthquake. No other report amongst the several contemporary ones, written by reliable eyewitnesses, and collected in the framework of the reappraisal of this earthquake performed by Albini (2015) corroborated the information supplied by Andriasci. Being this a unique information, referred to effects at a single location, expressed in a language reminding of biblical catastrophic events, it was reckoned to be insufficient to confirm that this earthquake caused a seawave.

At the time of this earthquake, in the area of study the settlements were mainly concentrated along the coast. This influenced the availability of earthquake observations and records, in their turn concentrated in a stretch of land facing the sea and closed by the range of the 
Table 3 Affected places in the Republic of Ragusa

\begin{tabular}{|c|c|c|c|c|c|c|}
\hline & Place name as quoted by the sources & Modern place name & Country today & Lat & Lon & Int EMS98 \\
\hline 1 & Ragusa & Dubrovnik & Croatia & 42.641 & 18.111 & 9 \\
\hline 2 & Ombla & Rijeka Dubrovačka, Mokošica and Rožat & Croatia & 42.676 & 18.095 & 9 \\
\hline 3 & Santa Croce (di Gravosa) & Gruž & Croatia & 42.659 & 18.087 & 9 \\
\hline 4 & Calamotta & Koločep, island and place & Croatia & 42.679 & 18.007 & $8-9$ \\
\hline 5 & Isola di Mezzo & Lopud, island and place & Croatia & 42.691 & 17.943 & $8-9$ \\
\hline 6 & Canali & Čilipi & Croatia & 42.549 & 18.287 & 8 \\
\hline 7 & Breno & Srebreno & Croatia & 42.623 & 18.196 & 8 \\
\hline 8 & Osonik & Osojnik & Croatia & 42.710 & 18.072 & 8 \\
\hline 9 & Orasciaz & Orašac & Croatia & 42.702 & 18.007 & 8 \\
\hline 10 & Tarsteno & Trsteno & Croatia & 42.714 & 17.979 & 8 \\
\hline 11 & Barsecine & Brsečine & Croatia & 42.731 & 17.960 & 8 \\
\hline 12 & Saton & Zaton & Croatia & 42.690 & 18.038 & 8 \\
\hline 13 & Ragusa Vecchia & Cavtat & Croatia & 42.581 & 18.218 & 8 \\
\hline 14 & Stagno Grande & Ston or Veliki Ston & Croatia & 42.839 & 17.696 & 8 \\
\hline 15 & S. Giacomo di Visegnizza & Sveti Jakov u Višnjici & Croatia & 42.636 & 18.132 & $7-8$ \\
\hline 16 & Giuppana & Suđurađ, Island of Šipan & Croatia & 42.711 & 17.909 & $7-8$ \\
\hline 17 & Primorie & Podgora, Dubrovačko primorje & Croatia & 42.838 & 17.843 & $7-8$ \\
\hline 18 & Meleda & Babino Polje, Island of Mljet & Croatia & 42.735 & 17.553 & $7-8$ \\
\hline 19 & Stagno Piccolo & Mali Ston & Croatia & 42.846 & 17.705 & $7-8$ \\
\hline 20 & Ponta & Prapratno & Croatia & 42.821 & 17.676 & $7-8$ \\
\hline 21 & Pridvorje & Pridvorje & Croatia & 42.551 & 18.350 & $7-8$ \\
\hline 22 & Slano & Slano & Croatia & 42.787 & 17.890 & $7-8$ \\
\hline
\end{tabular}

Table 4 Affected places in the Republic of Venice

\begin{tabular}{|c|c|c|c|c|c|c|}
\hline & Place name as quoted by the sources & Modern place name & Country today & Lat & Lon & Int EMS98 \\
\hline 1 & Scoglieto della Madonna & Gospa od Škrpjela & Montenegro & 42.486 & 18.691 & 8 \\
\hline 2 & Scoglieto di San Zorzi & Sveti Đorđe & Montenegro & 42.487 & 18.689 & 8 \\
\hline 3 & Perasto & Perast & Montenegro & 42.487 & 18.699 & 8 \\
\hline 4 & Budua & Budva, Stari Grad & Montenegro & 42.278 & 18.838 & 8 \\
\hline 5 & Cattaro & Kotor & Montenegro & 42.426 & 18.772 & 8 \\
\hline 6 & Zuppa, Contea di & Župa & Croatia & 42.360 & 18.760 & $7-8$ \\
\hline 7 & Castel di Lastua & Petrovac na moru & Montenegro & 42.206 & 18.940 & 7 \\
\hline
\end{tabular}

Table 5 Affected places in the Ottoman Empire

\begin{tabular}{|c|c|c|c|c|c|c|}
\hline & Place name as quoted by the sources & Modern place name & Country & Lat & Lon & Int EMS98 \\
\hline 1 & Castel Novo & Herceg Novi & Montenegro & 42.453 & 18.538 & 8 \\
\hline 2 & Antivari & Bar & Montenegro & 42.093 & 19.135 & 7 \\
\hline 3 & Subzi & Zubci & Montenegro & 42.128 & 19.116 & $6-7$ \\
\hline 4 & Tugemille & Tuđemili & Montenegro & 42.134 & 19.146 & $6-7$ \\
\hline 5 & Ptelicchi & Gornja Briska & Montenegro & 42.116 & 19.228 & $6-7$ \\
\hline 6 & Lastua & Žukovica & Montenegro & 42.227 & 18.956 & $6-7$ \\
\hline 7 & Dolcino & Ulcinj & Montenegro & 41.927 & 19.203 & $6-7$ \\
\hline 8 & Scutari & Shkodër & Albania & 42.068 & 19.513 & 6 \\
\hline
\end{tabular}




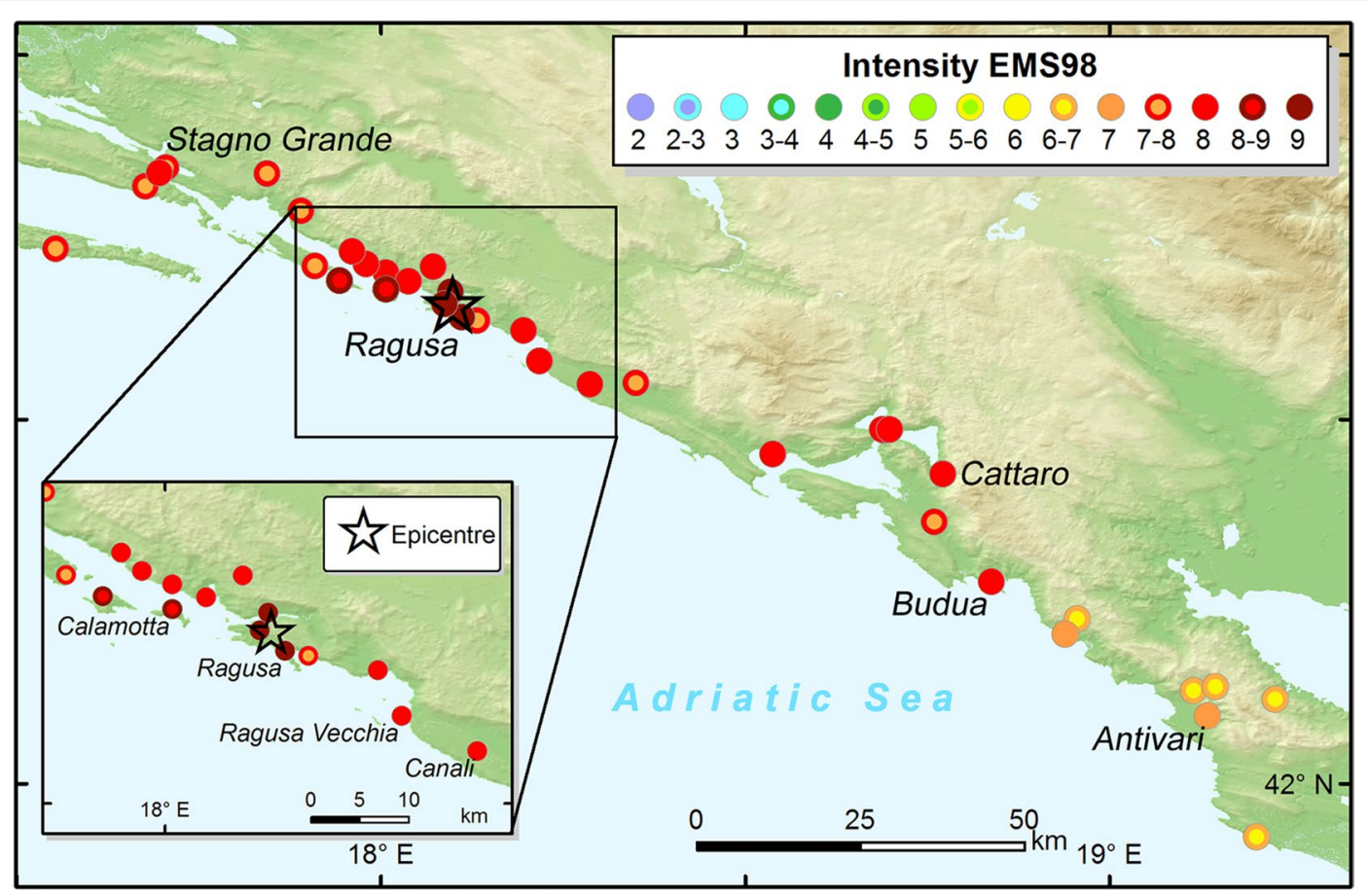

Fig. 6 Macroseismic intensities in EMS98, epicentre of the 6 April 1667 earthquake, with Mw $6.4 \pm 0.3$

Dinarides in the background. This explains the rather peculiar intensity distribution for the 6 April 1667 earthquake (Fig. 6), with intensities $\geq 6$ EMS98 assigned to a set of coastal settlements aligned in a NW-SE direction, and with very scarce observations on inland localities. These aspects made the parameters' determination particularly tricky, especially as concerns the earthquake location, and independently from the chosen method amongst the ones currently used to assess seismic parameters from macroseismic data. The new, and sound, set of macroseismic intensities was processed according to the Boxer method (Gasperini et al. 1999, 2010). This method determines the location of the epicentre as the barycenter of the places with the highest intensities, and calculates the magnitude as the average of the values obtained for each intensity class, considering the intensity attenuation a function of $\mathrm{Mw}$ and epicentral distance. The macroseismic epicentre calculated for the 6 April 1667 is close to Ragusa/Dubrovnik $\left(42.659^{\circ} \mathrm{N} ; 18.098^{\circ} \mathrm{E}\right)$, in the area of the most severe effects (Fig. 6). However, an epicentre located at sea, a few kilometres from the coast, would be an alternative to contemplate. The assessed magnitude is Mw $6.4 \pm 0.3$, which is consistent with the extent of the most damaged area, stretching for $100 \mathrm{~km}$ along the coast. Taking into account the peculiarities of the data and the limitations of the Boxer method, the resulting seismic parameters are a convincingly located epicentre and a reasonable magnitude value for the 6 April 1667 earthquake.

\section{Conclusions}

The comprehensive review of the Dalmatia earthquake of 6 April 1667, occurred at about 8.45 a.m., with a duration of $8-15 \mathrm{~s}$, resulted in a reappraised set of 37 macroseismic intensities in EMS98. Processing the newly assessed and enriched set of intensity data, the earthquake epicentre was located close to Ragusa/Dubrovnik, with an estimated magnitude of Mw 6.4 \pm 0.3 .

Some misunderstandings contained in previous interpretations of the historical documents have been corrected, and for instance, it was excluded that damage did reach Zara (N Dalmatia), as well as that the earthquake triggered any seawave. In addition, the spatial distribution of intensity values was extended in a significant way, especially to the south of Ragusa/Dubrovnik (Croatia), in the area then ruled by the Ottoman Empire (today Montenegro).

In all, the newly retrieved earthquake records have made macroseismic intensities more than double in the most damaged area, although most observations are related to coastal settlements, only. However, still missing is a comparably good set of records of less intense effects (<6 EMS98), which either were not considered worth reporting by contemporary observers, or simply 
have been shadowed by those who left testimonies on the heavily struck places.

\section{Authors' contributions}

PA authored the book "The Great 1667 Dalmatia Earthquake" from which data presented in this paper up to macroseismic intensity assignment are based on. AR carried out the seismic parameters calculations. Authors shared drafting the manuscript. Both authors read and approved the final manuscript.

\section{Competing interests}

The authors declare that they have no competing interests.

Received: 14 September 2016 Accepted: 28 October 2016

Published online: 09 November 2016

\section{References}

Albini P (2015) The Great 1667 Dalmatia Earthquake. An in-depth case study, Springer briefs in earth sciences, The Netherlands. "Extra Materials" at https://extras.springer.com/2015/978-3-319-16207-2

Anderson H, Jackson J (1987) Active tectonics of the Adriatic region. Geophys J R Astron Soc 91(3):937-983. doi:10.1111/j.1365-246X.1987.tb01675.x Andriasci V (1667) Lettera di Ragguaglio, nella quale si sente la totale distruzione della Città di Ragusa dal Terremuoto quest'anno li 6 Aprile a ore 14 li Mercoledì Santo Scritta dal molto Reverendo Padre Fra Vitale Andriasci da Ragusa de' Minori Osservanti al Molto Illustre Signore Diodono Bosdari in Ancona. In Ancona nella Stamperia Camerale MDCLXVIII, Con licenza de'Superiori

Gasperini P, Bernardini F, Valensise G, Boschi E (1999) Defining seismogenic sources from historical earthquake felt reports. Bull Seism Soc Am 89:94-110

Gasperini P, Vannucci G, Tripone D, Boschi E (2010) The location and sizing of historical earthquakes using the attenuation of macroseismic intensity with distance. Bull Seismol Soc Am 100:2035-2066

Grünthal G (ed) (1998) European macroseismic scale 1998 EMS-98. Cahiers du Centre Européen de Géodynamique et de Séismologie, v. 15, p 99

Ivančić I, Herak D, Markušić S, Sović I, Herak M (2006) Seismicity of Croatia in the period 2002-2005. Geofizika 23(2):87-103

Loredan G (1669) 'Relazione' (report) by Giacomo Loredan, Provveditore Estraordinario a Cattaro. Archivio di Stato di Venezia, Collegio, V (Secreta), Relazioni, b. 65, ff. $1 \mathrm{r}-6 \mathrm{v}+$ enclosures

Molin A (1668) Diario della speditione dell'Ill.mo et Ecc.mo Signor Alvise da Molin Cavagliere alla Corte del Gran Signor. Archivio di Stato di Venezia, Miscellanea di atti diversi manoscritti, f 54

Musson RMW, Cecić I (2002) Macroseismology. In: Lee WHK, Kanamori H, Jennings PC, Kisslinger C (eds) International handbook of earthquake and engineering seismology. Academic, San Diego, pp 807-822

Zmaievich A (1671) 'Relazione' (report) dell'arcivescovo della diocesi di Antivari e del Vicariato di Budua, di Andrea Zmaievich della Sacra Congregazione per la diffusione della Fede. In: Gelcich G (1883). Biblioteca Storica della Dalmazia, vol 8, Documenti, n.37, p 105-120

\section{Submit your manuscript to a SpringerOpen ${ }^{\circ}$ journal and benefit from:}

- Convenient online submission

- Rigorous peer review

- Immediate publication on acceptance

- Open access: articles freely available online

- High visibility within the field

- Retaining the copyright to your article 